\title{
Inhibitory Effects of OKY-046 on Spasmogen-Induced Bronchoconstrictions in Sensitized and Non-Sensitized Guinea Pigs
}

\author{
Fumio NAMBU, Mariko MOTOISHI, Nagashige OMAWARI, \\ Tadao OKEGAWA, Akiyoshi KAWASAKI and Shigeru IKEDA 1 \\ Minase Research Institute, Ono Pharmaceutical Co., Ltd., \\ 3-1-1 Sakurai, Shimamoto-cho, Mishima-gun, Osaka 618. Japan \\ ${ }^{1}$ Central Research Laboratories, Research Institute. Kissei Pharmaceutical Co., Ltd., \\ 19-48 Yoshino, Matsumoto, Nagano 399. Japan
}

Accepted October 18, 1989

\begin{abstract}
We examined the effect of thromboxane $A_{2}\left(T X A_{2}\right)$ synthetase inhibitor, $\mathrm{OKY}-046$, on bronchoconstriction induced by antigen and various spasmogenic mediators in guinea pigs in vivo. Further, inhibitory activities of OKY-046 on contractions of isolated tracheae and lung parenchymal strips induced by various contractile agents were also investigated in vitro. OKY-046, but not indomethacin. significantly inhibited antigen-induced bronchoconstriction in a dose-dependent manner. Moreover, OKY-046 attenuated bronchoconstrictions induced by peptide leukotrienes (LTs) and platelet activating factor (PAF), but not those by histamine. prostaglandin $D_{2}\left(P_{G}\right.$ ) and $\mathrm{STA}_{2}$ (a stable $\mathrm{TXA}_{2}$ mimetic agent). Although contractile responses induced by spasmogens such as peptide LTS, PAF and histamine were not influenced by OKY-046 in isolated tracheae. OKY-046 elicited significant and concentration-dependent inhibitions against contractile responses induced by peptide LTs and PAF in isolated lung parenchymal strips. These results suggest the possible involvement of $\mathrm{TXA}_{2}$ in the development of anaphylactic bronchoconstriction in sensitized guinea pigs.
\end{abstract}

The release of eicosanoids from lung tissues in response to immunological stimuli has been described previously $(1,2)$. Among eicosanoids, thromboxane $A_{2}\left(T \times A_{2}\right)$, which is produced by platelets, mononuclear leukocytes, lung mast cells and other cells, has been considered as one of the important mediators $(3-7)$ in inflammatory respiratory diseases such as asthma, since it has potent contractile activities on pulmonary airways and blood vessels $(4,8)$ beside promoting platelet aggregation. However, the activity of $\mathrm{TAX}_{2}$ on airway function in vivo has been difficult to assess due to the short half-life of this mediator in blood (9).

In the present study, we examined the role of $\mathrm{TXA}_{2}$ in anaphylactic bronchoconstriction by using a potent and selective TXA $\mathrm{A}_{2}$ synthetase inhibitor, (E) - $3-[\mathrm{p}-(1 \mathrm{H}$-imidazol-1ylmethyl) phenyl]-2-propenoic acid (OKY-
046) (10), in the guinea pig. Furthermore, inhibitory activities of OKY-O46 on bronchoconstriction responses induced by various spasmogenic mediators such as histamine. peptide leukotrienes (LTs) and platelet activating factor (PAF) were also investigated both in vivo and in vitro.

\section{Materials and Methods}

\section{Animals}

Male Hartley guinea pigs weighing 250 to $500 \mathrm{~g}$ were used throughout the experiments. Drug

Either the sodium or hydrochloride salt of OKY-046 was used. Leukotriene (LT) $C_{4}$, $\mathrm{LTD}_{4}, \quad \mathrm{LTE}_{4}, \quad \mathrm{PGD}_{2}, \quad 9,11$-epithio-11.12methano-TXA (STA $_{2}$, a stable TXA 2 mimetic agonist) and platelet activating factor (PAF) were synthesized by Ono. LTC $4, L_{4} D_{4}$ and $\mathrm{LTE}_{4}$ (dissolved in 50\% ethanol) and $\mathrm{PGD}_{2}$ 
(dissolved in absolute ethanol) were diluted with 1/15 $M$ phosphate-buffered solution (pH 7.4). STA 2 was dissolved in $1 / 15 \mathrm{M}$ phosphate-buffered solution $(\mathrm{pH} \mathrm{7.4)}$. and PAF was dissolved in absolute ethanol and diluted accordingly with physiological saline containing $0.25 \%$ bovine serum albumin (BSA, Fraction V, Sigma). Histamine dihydrochloride (Sigma), acetylcholine chloride (Ovisot ${ }^{\circledR}$. Daiichi Seivaku), carbachol (Sigma), ovalbumin (OVA, Grade III, Sigma) and BSA were dissolved in physiological saline. Indomethacin and killed Bordetella pertussiss were purchased from Sigma and Chemo-Sero-Therapeutic Research Institute, respectively. The composition of KrebsHenseleit solution was as follows: $118 \mathrm{mM}$ $\mathrm{NaCl}, 4.7 \mathrm{mM} \mathrm{KCl}, 2.5 \mathrm{mM} \mathrm{CaCl}_{2}, 1.2 \mathrm{mM}$ $\mathrm{MgSO}_{4}, 1.2 \mathrm{mM} \mathrm{KH}_{2} \mathrm{PO}_{4}, 25 \mathrm{mM} \mathrm{NaHCO}_{3}$ and $5.6 \mathrm{mM}$ glucose.

\section{Drug administration}

For in vivo studies, OKY -046 and indomethacin were dissolved in physiological saline and $7 \%$ sodium bicarbonate, respectively. Both were administered i.v. 2 min prior to challenge with antigen or various other spasmogens. For in vitro studies, OKY-046 was dissolved in physiological saline and added into the organ bath 20 min before challenge with various contractile agents.

\section{In vivo experiment}

Sensitization procedure: The animals were injected intraperitoneally with $1 \mathrm{mg}$ OVA containing $5 \times 10^{9}$ killed Bordetella pertussiss on day 0 . The injection volume was $0.5 \mathrm{ml}$. Sensitized animals were challenged by i.v.administration of OVA on days 15 to 17 . The antibody produced in this sensitization procedure belonged to the $\lg G$ class when assessed by $4 \mathrm{hr}$ - and 8 day-homologous passive cutaneous anaphylactic reactions (11).

Measurement of bronchoconstriction: A small cannula was inserted into the surgically exposed trachea of the pentobarbital-anesthetized ( $75 \mathrm{mg} / \mathrm{kg}$. i.p.) animal and secured tightly with ligatures. Two other cannulae were inserted into the carotid artery and jugular vein separately for monitoring systemic blood pressure and administration of drugs and antigen, respectively. The tracheal cannula was connected to a constant volume respirator, and the animal was artificially ventilated at a constant volume of $5 \mathrm{ml}$ at a frequency of $70 \mathrm{strokes} / \mathrm{min}$. Changes in insufflation pressure at a constant airflow were measured by a pressure transducer connected to the side-arm of the trachea! cannula and expressed as a percentage of the maximal increase in insufflation achieved by clamping off the trachea at the end of the experiment.

Effects on antigen- and spasmogeninduced bronchoconstriction: A single bolus i.v.-injection of OVA $(0.2 \mathrm{mg} / \mathrm{kg})$ produced approximately $70 \%$ of the maximal bronchoconstriction in preliminary experiments. Bronchoconstriction after OVA challenge was monitored for $15 \mathrm{~min}$. $\mathrm{LTC}_{4}(2.0 \mu \mathrm{g} / \mathrm{kg})$, $\mathrm{LTD}_{4}(2.0$ or $0.5 \mu \mathrm{g} / \mathrm{kg}), \mathrm{LTE}_{4}(5.0 \mu \mathrm{g} / \mathrm{kg})$ PAF $(0.3 \mu \mathrm{g} / \mathrm{kg})$ and PGD $2(100 \mu \mathrm{g} / \mathrm{kg})$ were intravenously administered. Histamine (10 $\mu \mathrm{g} / \mathrm{kg}$, i.v.) and $\mathrm{STA}_{2}(3.0 \mu \mathrm{g} / \mathrm{kg}$, i.v.) were administered several times until constant airway responses were obtained.

\section{In vitro experiment}

Preparation of guinea pig tracheal and lung parenchymal strips: The animals were sacrificed by a sharp blow to the head. exanguinated, and the tracheae and lungs were isolated. Tracheae were carefully trimmed of excess fatty and connective tissues and cut into zigzag strips of equal number of segments. The lung parenchvmal strips were removed from the outer edge of the right and left lower lobes of the lung. Each preparation was suspended under $0.5 \mathrm{~g}$ of passive tension in a $10-\mathrm{ml}$ organ bath containing KrebsHenseleit solution, which was maintained at $37^{\circ} \mathrm{C}, \mathrm{pH} 7.4$, and continuously aerated with $95 \% \mathrm{O}_{2}-5 \% \mathrm{CO}_{2}$. Contractions of these tissues were measured by using an isotonic transducer (Nihon Kohden, TD112S) for the tracheal strip and a force-displacement transducer (Nihon Kohden. TB611T) for the lung parenchymal strip. After each tissue was equilibrated for 0.5 to $1 \mathrm{hr}$ before commencement of the experiment, constant responses to carbachol $\left(10^{-6} \mathrm{M}\right)$ for tracheal strips and acetylcholine $\left(10^{-5} \mathrm{M}\right)$ for lung parenchymal strips were obtained at least twice.

\section{Effect of spasmogen-induced contractile re-} sponses

After a maximally effective concentration of carbachol $\left(10^{-5} \mathrm{M}\right)$ for tracheal strips or 
acetylcholine $\left(10^{-3} \mathrm{M}\right)$ for parenchymal strips was obtained, cumulative concentration-response curves for contractile agonists, i.e., histamine, $\mathrm{LTC}_{4}, \mathrm{LTD}_{4}, \mathrm{STA}_{2}$ and $P G D_{2}$, were constructed by successive increases in the bath concentration of these agonists. In the case of PAF, all strips obtained from the same animal were challenged with only one concentration of this agonist because of its tachyphylactic effect (12). To minimize the variation between tissues of animals, contractile responses were expressed as a percentage of the maximal response with carbachol $\left(10^{-5} \mathrm{M}\right)$ or acetylcholine $\left(10^{-3} \mathrm{M}\right)$.

\section{Statistical evaluation}

Statistical evaluations were made by Student's unpaired or paired t-test, with a probability value of $P<0.05$ regarded as significant.

\section{Results}

In vivo

Inhibitory activities on antigen-induced bronchoconstrictions: Administration of antigen in sensitized guinea pigs produced a bronchoconstriction with rapid onset (within $30 \mathrm{sec}$ ) and long-lasting action (more than $15 \mathrm{~min}$ ) characterized by large increases in insufflation pressure $(77.3 \pm 4.8 \%$ of maximal increase at $4 \mathrm{~min}$ ) and a temporal but an abrupt hypertension $(34.4 \pm 8.4 \mathrm{mmHg}$ at 2 min) followed by slight hypotension $(-6.3 \pm$ $2.2 \mathrm{mmHg}$ at $15 \mathrm{~min}$ ). The peak in bronchoconstriction and hypertension occurred approximately 2 to $5 \mathrm{~min}$ and 1 to $3 \mathrm{~min}$ after antigen challenge, respectively. OKY-046 significantly inhibited both bronchoconstriction and hypertension induced by antigen in a dose-dependent manner at doses ranging
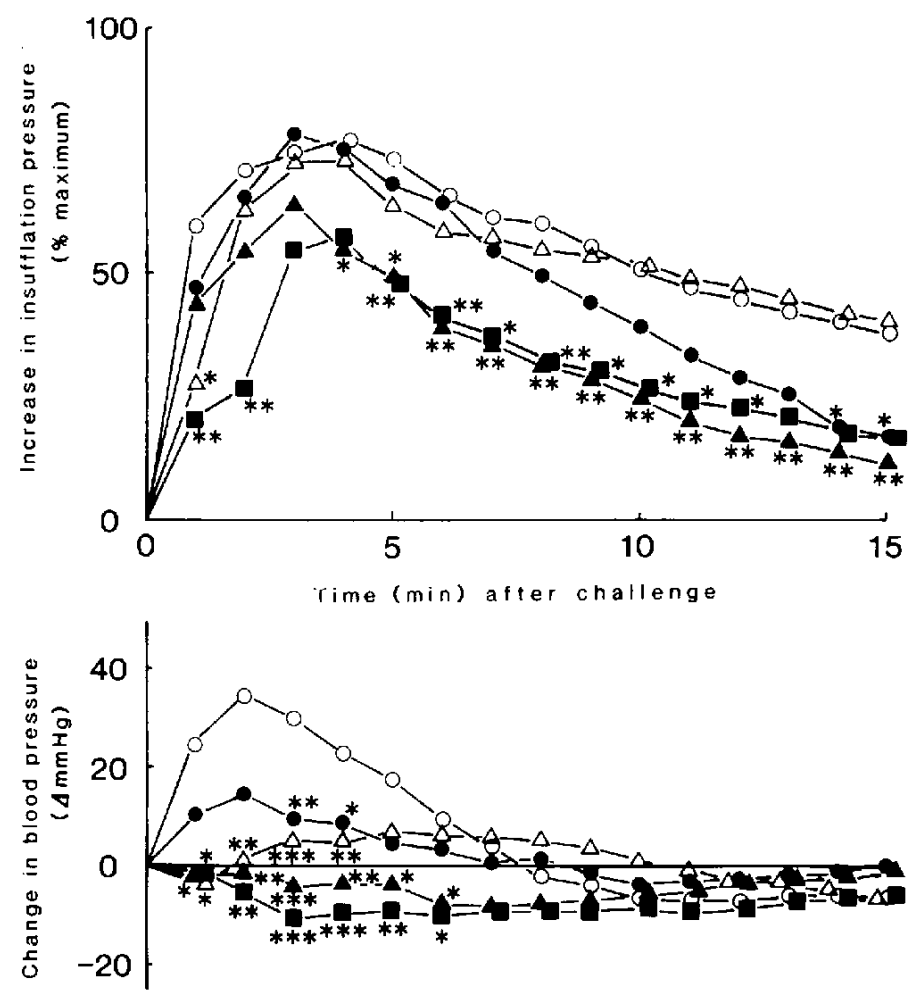

Fig. 1. Effects of $\mathrm{OKY}-046$ and indomethacin on antigen-induced bronchoconstrictions and blood pressure responses in sensitized guinea pigs. Each point represents the mean of each group. $O-O$ :

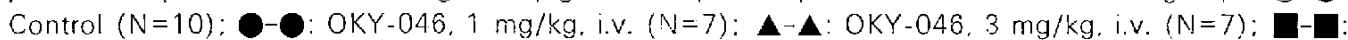
OKY-046. $10 \mathrm{mg} / \mathrm{kg}$, i.v. $(N=7): \triangle-\Delta$ : indomethacin, $2 \mathrm{mg} / \mathrm{kg}$. i.v. $(N=8) . \quad *$ * and ** indicate significant differences compared with the control where $\mathrm{P}<0.05, P<0.01$ and $\mathrm{P}<0.001$, respectively. 
from 1 to $10 \mathrm{mg} / \mathrm{kg}$. On the other hand. indomethacin significantly inhibited this airway response only within 1 min after challenge, although it almost prevented the pressor response (Fig. 1).

Inhibitory activities on responses induced by various spasmogens: OKY-046, when given as a single bolus i.v.-injection, had no inhibitory effects on histamine $(10 \mu \mathrm{g} / \mathrm{kg}$. i.v.) -, $\mathrm{PGD}_{2}\left(100 \mu \mathrm{g} / \mathrm{kg}\right.$. i.v.) - and $\mathrm{STA}_{2}$ (3 $\mu g / \mathrm{kg}$. i.v.)-induced bronchoconstrictions at the dose of $30 \mathrm{mg} / \mathrm{kg}$ (Table 1).

Intravenous administration of $\mathrm{LTC}_{4}(2 \mu \mathrm{g} /$ $\mathrm{kg})$ produced a biphasic bronchoconstriction with peaks that appeared at $30-60 \mathrm{sec}$ and 3-4 min, and elicited a transient hypertensive effect followed by hypotension 2 to $4 \mathrm{~min}$ after administration (Fig. 2). OKY-046 preferentially inhibited the initial phase at doses ranging from 0.1 to $1 \mathrm{mg} / \mathrm{kg}$, but had no influence on the latter phase of bronchoconstriction. Indomethacin also inhibited the air-

Table 1. Effects of OKY-O46 on histamine-, STA - and $P G D_{2}$-induced bronchoconstrictions in guinea pigs

\begin{tabular}{|c|c|c|c|c|c|}
\hline \multirow{2}{*}{ Spasmogens } & \multirow{2}{*}{$\begin{array}{c}\text { Dose } \\
(\mu \mathrm{g} / \mathrm{kg}, \mathrm{i} . \mathrm{v} .)\end{array}$} & \multirow{2}{*}{$N$} & \multicolumn{2}{|c|}{$\begin{array}{l}\text { Increase in insufflation pressure } \\
\text { (\% max.) }\end{array}$} & \multirow{2}{*}{ P value } \\
\hline & & & Contral & OKY-046 & \\
\hline Histamine & 10 & 5 & $63.8 \pm 4.3$ & $66.1 \pm 3.9$ & $>0.1$ \\
\hline $\mathrm{STA}_{2}$ & 3 & 5 & $60.5 \pm 3.1$ & $60.9 \pm 2.3$ & $>0.1$ \\
\hline $\mathrm{PGD}_{2}$ & 100 & 5 & $45.6 \pm 5.4$ & $55.4 \pm 9.6$ & $>0.1$ \\
\hline
\end{tabular}

OKY-046 was intravenously administered 2 min prior to injection of each agonist at the dose of $30 \mathrm{mg} / \mathrm{kg}$. Each value represents the mean $\pm S$.E.M. Significant difference compared to the contro! was determined using Student's paired $t$-test for histamine and STA 2 or the unpaired $t$-test for $P G D_{2}$.

Insufflation Pressure
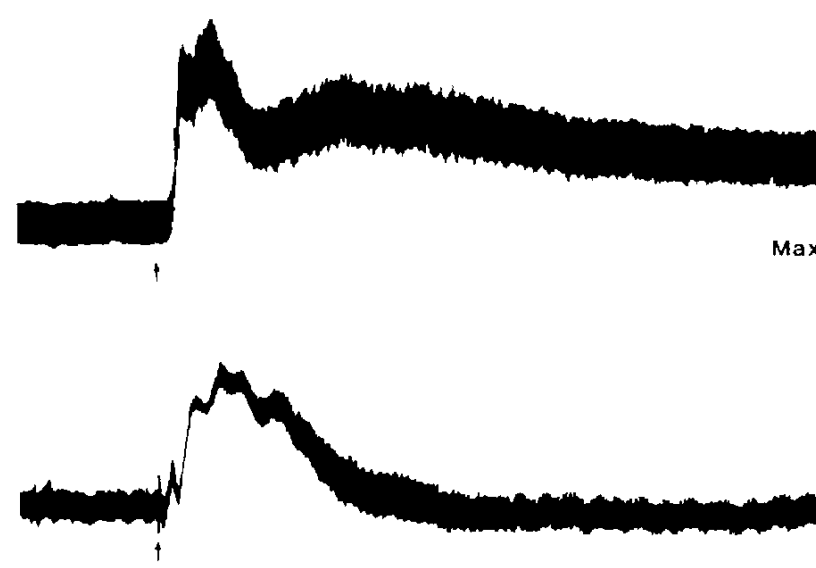

$\mathrm{LTC}_{4}, 2 \mu \mathrm{g} / \mathrm{kg}, \mathrm{i} . \mathrm{v}$.

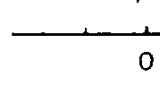

Blood Pressure

0

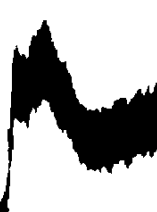

Maximum Response

$\operatorname{Time}(\mathrm{min})$

Fig. 2. Time-related changes ini insufflation pressure and blood pressure after injection of LTC $4(2 \mu 9 /$ kg, i.v.). 
way response within $1 \mathrm{~min}$, but augmented the response at 3 and 4 min after $\mathrm{LTC}_{4}$ challenge. Pressor responses induced by $\mathrm{LTC}_{4}$ were abolished and turned into depressor responses by OKY-046 (Fig. 3). OKY-046 elicited similar inhibitory effects on $\mathrm{LTD}_{4}$ (2 $\mu \mathrm{g} / \mathrm{kg}$, i.v.) - and $\mathrm{LTE}_{4}(5 \mu \mathrm{g} / \mathrm{kg}$, i.v.) induced responses that resembled those of $\mathrm{LTC}_{4}$ (data not shown). Pretreatment of indomethacin abolished LTD $4 \quad(0.5 \mu \mathrm{g} / \mathrm{kg})$ induced rapid airway response when compared with the response without indomethacin pretreatment. OKY-046 (10 mg/ $\mathrm{kg}$, i.v.) did not show any inhibitory effects on bronchoconstrictions induced by $\mathrm{LTD}_{4}$ in the presence of indomethacin (Fig. 4).

Intravenous administration of PAF 10.3 ,$/ \mathrm{g} / \mathrm{kg}$ ) elicited temporal bronchoconstrictions with rapid onset (within $30 \mathrm{sec}$ ). An increase in insufflation pressure of $61.9 \pm$ $7.9 \%$ was accompanied by a transient increase followed by a sustained fall ( 3 to 10 $\mathrm{min}$ ) in blood pressure. OKY 046 showed a dose-dependent attenuation against bronchoconstriction and hypertension at doses ranging from 1 to $10 \mathrm{mg} / \mathrm{kg}$. Indomethacin also
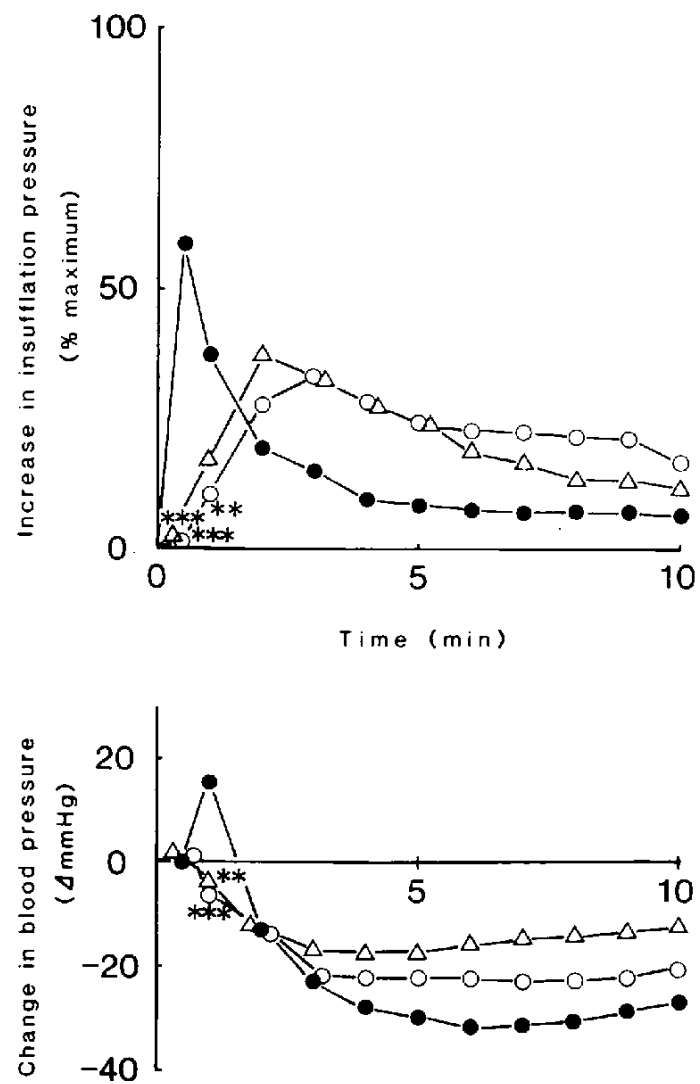

Fig. 3. Effects of OKY-046 and indomethacin on $\mathrm{LTC}_{4}(2 \mu \mathrm{g} / \mathrm{kg}$. i.v.)-induced bronchoconstrictions and blood pressure responses in guinea pigs. Each point represents the mean of each group.

-O : Control $(\mathrm{N}=10)$ : $\mathrm{O}-\mathrm{O}$ : OKY-046, $0.1 \mathrm{mg} / \mathrm{kg}, \mathrm{i} . \mathrm{V}$. $(N=7): \triangle-\triangle: O K Y-046.0 .3 \mathrm{mg} / \mathrm{kg}$, i.v. $(N=7)$ : $\square-\square:$ OKY-046. $1 \mathrm{mg} / \mathrm{kg}$. i.v. $(\mathrm{N}=7): \Delta-\mathbf{A}$ : indomethacin, $2 \mathrm{mg} / \mathrm{kg}$, i.v. $(\mathrm{N}=3) .{ }^{*},{ }^{* *}$ and ${ }^{* * *}$ indicate significant differences compared with the control where $P<0.05, P<0.01$ and $P<0.001$. respectively.
Fig. 4. Time-related changes in insufflation pressure and blood pressure in response to $\mathrm{LTD}_{4}(0.5 \mu \mathrm{g} / \mathrm{kg}$. i.v.) in the presence $(\mathrm{O}-\mathrm{O}, \mathrm{N}=3$ ) or absence (O-O. $\mathrm{N}=3$ ) of indomethacin (2 $\mathrm{mg} / \mathrm{kg}, i . v$.) and the effect of OKY $-046(\triangle-\triangle .10 \mathrm{mg} / \mathrm{kg}, \mathrm{i} . \mathrm{v} ., \mathrm{N}=3$ ) on $\mathrm{LTD}_{4}$-induced responses in indomethacin-treated guinea pigs. Each point represents the mean of each group. ** and *** indicate significant differences in comparison with the non-treated control where $\mathrm{P}<$ 0.01 and $P<0.001$, respectively. 
significantly attenuated the spasmogenic and hypertensive activities of PAF (Fig. 5).

In vitro

In isolated tracheal strips, OKY-046 $\left(10^{-4}\right.$ $M)$ did not show any inhibitory activities against contractile responses induced by histamine, $\mathrm{PGD}_{2}, \mathrm{STA}_{2}, \mathrm{LTC}_{4}$ and $\mathrm{LTD}_{4}$ (Table 2).

In isolated lung parenchymal strips, OKY $046\left(10^{-4} \mathrm{M}\right)$ similarly did not show any inhibitory effects on the contractile responses induced by histamine. $\mathrm{PGD}_{2}$ and STA 2 (Table 2). However, OKY-046 $\left(10^{-5}-10^{-4} M\right)$ produced significant and concentration-dependent inhibitions on $\mathrm{LTD}_{4}$-induced con- tractions and shifted the concentrationresponse curve towards the right in lung parenchymal strips (Fig. 6). Indomethacin also showed significant inhibitions on $\mathrm{LTD}_{4}^{-}$ induced contractions in lung parenchyma! strips (Fig. 6). OKY-046 or indomethacin inhibited PAF-induced contraction in a concentration-dependent manner (Fig. 7).

\section{Discussion}

We investigated the effect of OKY-046 on experimental asthma in sensitized guinea pigs. The present study conifrmed that OKY046, but not indomethacin, elicited a dosedependent inhibitory effect on antigen-
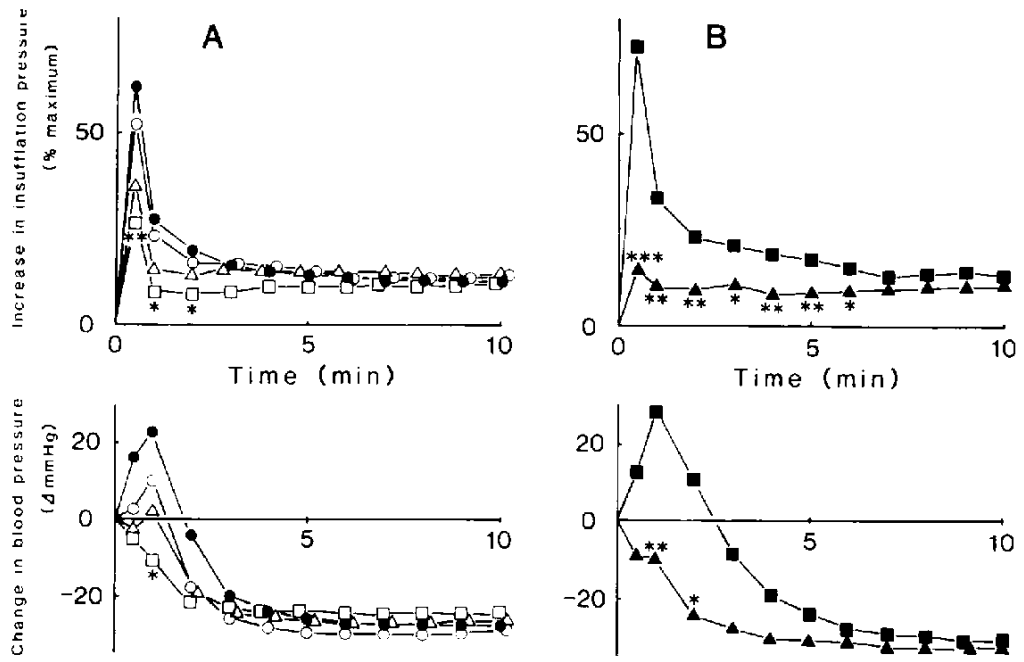

Fig. 5. Effects of OKY-046 (A) and indomethacin (B) on PAF (0.3 $\mu \mathrm{g} / \mathrm{kg}$, i.v.)-induced bronchoconstrictions and blood pressure responses in guinea pigs. Each point represents the mean of each group. A: - Control $(N=5): O-O . O K Y-046.1 \mathrm{mg} / \mathrm{kg}, \mathrm{i} . \mathrm{V} .(\mathrm{N}=5): \triangle-\triangle . O K Y-046.3 \mathrm{mg} / \mathrm{kg}, \mathrm{i} . \mathrm{V} .(\mathrm{N}=5):$ $\square-\square, O K Y-046,10 \mathrm{mg} / \mathrm{kg}$, i.v. $(\mathrm{N}=5)$. B: $\square$. Control $(\mathrm{N}=5)$ : $\mathbf{A}-\mathbf{A}$, indomethacin, $2 \mathrm{mg} / \mathrm{kg}, \mathrm{i} . \mathrm{v}$. $(N=5) . *{ }^{* *}$, and *** indicate significant differences in comparison with the control where $P<0.05$ $\mathrm{P}<0.01$ and $\mathrm{P}<0.001$, respectively.

Table 2. Effects of OKY-046 on contractile responses induced by various spasmogens in guinea pig trachea and lung parenchymal strips

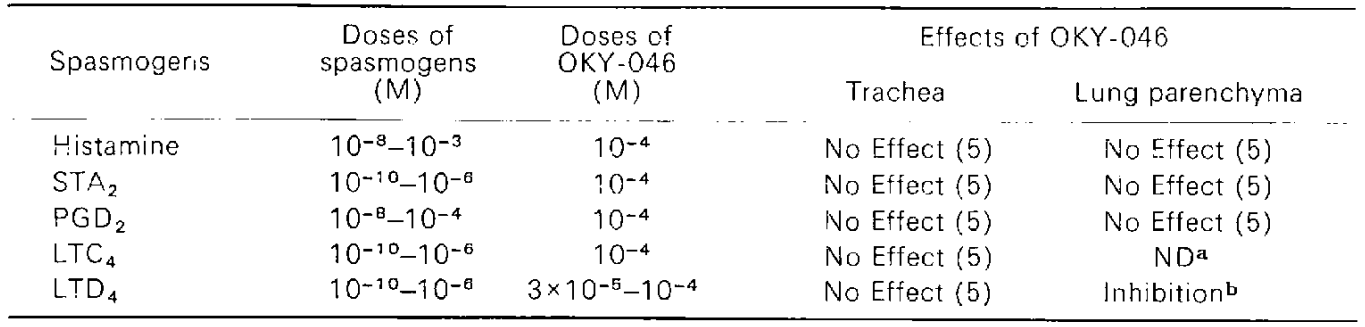

Numbers in parentheses indicate the number of preparations used. a not done. b See Fig. 6. 


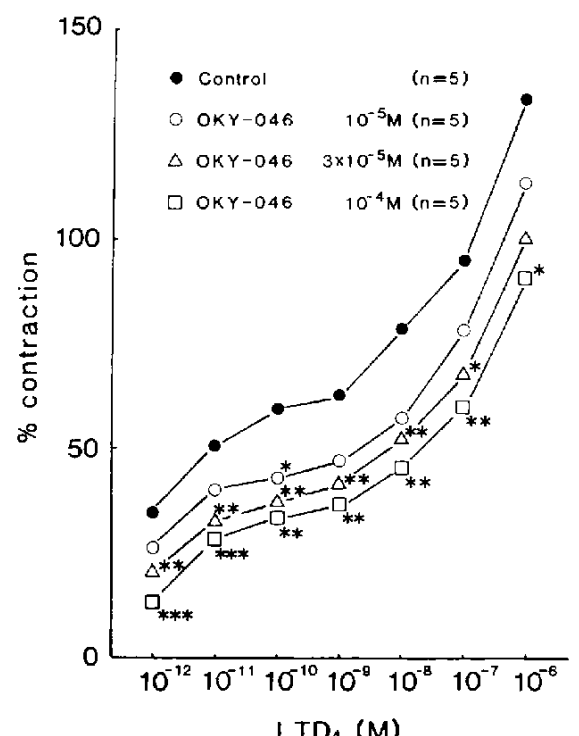

$\mathrm{LTD}_{4}(\mathrm{M})$

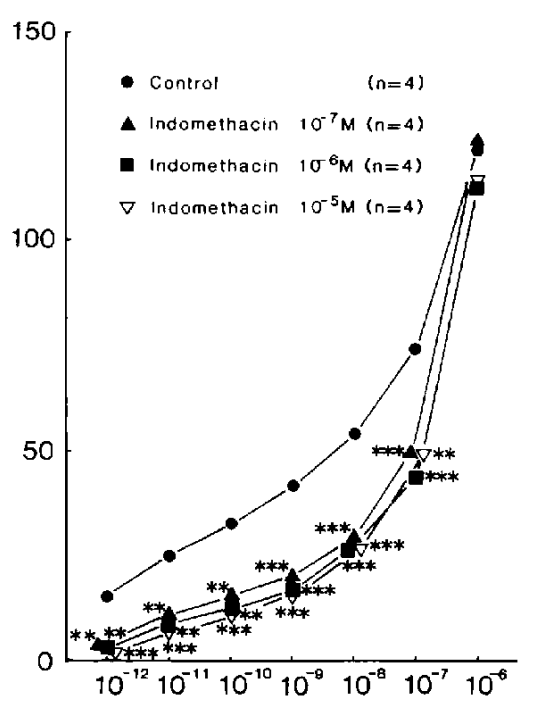

$\mathrm{LTD}_{4}(\mathrm{M})$

Fig. 6. Effects of $O K Y-046$ and indomethacin on contractile response induced by $L_{T} D_{4}$ in guinea pig lung parenchymal strips. Each point represents the mean value. Numbers in parentheses represent the numbers of preparations used.,$^{* *}$ and ${ }^{* * *}$ indicate significant differences compared with the control where $P<0.05, P<0.01$ and $P<0.001$, respectively.
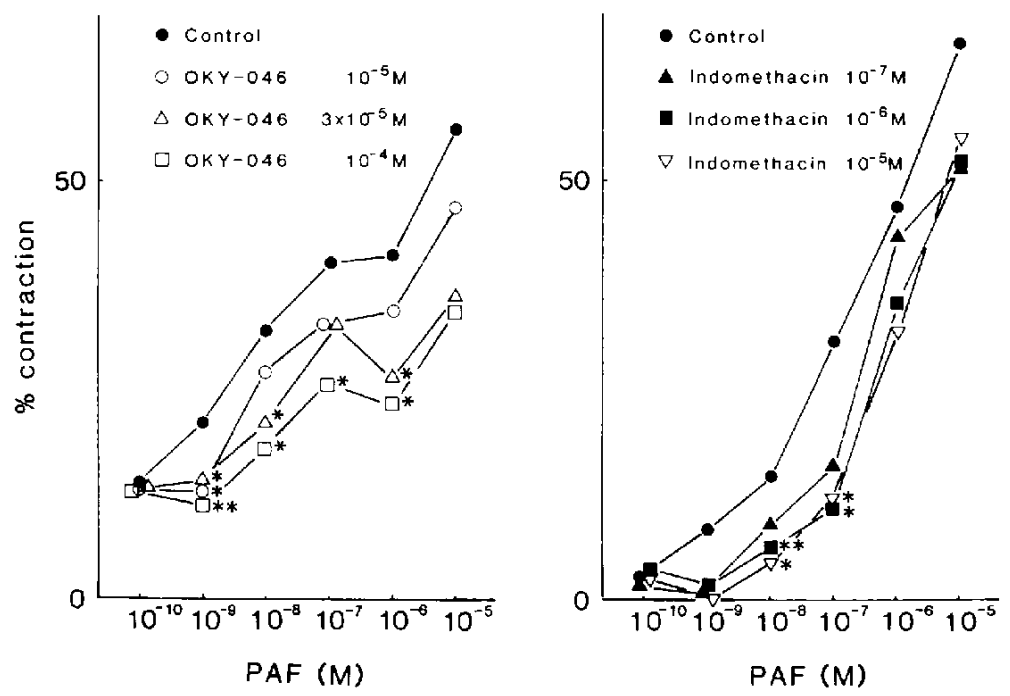

Fig. 7. Effects of OKY 046 and indomethacin on contractile response induced by PAF in guinea pig lung parenchymal strips. Each point represents the mean value of 4 to 7 preparations. * and ** indicate significant differences compared with the control where $P<0.05$ and $P<0.01$, respectively.

induced bronchoconstriction. Since various spasmogens are considered to play important roles in mediating anaphylactic reactions, we examined the effect of OKY-046 on spasmogen-induced bronchoconstrictions.
In our in vitro studies, OKY-046 showed no effect on the contractile responses induced by histamine. STA $A_{2}$ and $\mathrm{PGD}_{2}$ in both tracheae and lung parenchymal strips. The findings suggest that such spasmongen-induced air- 
way tissue contractions are not mediated via the actions of $\mathrm{TXA}_{2}$, and OKY-046 has no direct antagonism against the actions of these spasmogens.

$\mathrm{LTD}_{4}$-induced contractions of lung parenchymal strips were significantly attenuated by either OKY-046 or indomethacin. Weichman et al. (13) reported that peptide LTs-induced contractions may be mediated in part by contractile cyclooxygenase metabolites in lung parenchymal strips. Furthermore, evidences that $\mathrm{TXA}_{2}$ is released from lung parenchyma when stimulated with peptide LTs have been documented $(13,14)$. Therefore, the present in vitro studies suggest that $T X A_{2}$ is a strong candidate for the contractile cyclooxygenase metabolite in mediating peptide LTs-induced contractions of lung parenchymal strips. However. the origin of $\mathrm{TXA}_{2}$ in lung parenchyma is unclear, although $T_{2} A_{2}$ is produced by platelets, mononuclear leukocytes, mast cells and other cells (3-7). On the other hand. OKY-046 did not show any inhibitory effects on the contractile responses induced by $\mathrm{LTC}_{4}$ or $\mathrm{LTD}_{4}$ in guinea pig tracheae. This suggests that the involvement of $\mathrm{TXA}_{2}$ on peptide LTs-induced tracheal contractions can be discounted. Although guinea pig trachea is capable of synthesizing TXA $\mathrm{A}_{2}$, the major cyclooxygenase product produced by this tissue is $P G E_{2}$ (15). On the other hand, Ally et al. (16) demonstrated that guinea pig lung parenchyma synthesizes predominantly $T_{X A_{2}}$. Therefore, it is conceivable that different effects of OKY-046 on trachea and lung parenchyma may be due to the difference in the amounts of $\mathrm{TXA}_{2}$ produced by peptide LTs in these two tissues.

It has been shown that peptide LTs are released from sensitized guinea pig lung fragment stimulated with antigen (17) and have potent contractile activities on airway tissues in vivo and in vitro (18-21). Also Andersson (22) reported that peptide LTs are involved in anaphylactic bronchoconstriction using a specific $L T$ antagonist FPL 55712. In the present in vivo study, we showed that OKY-046 attenuated transient bronchoconstriction and hypertension induced by peptide LTs. OKY-O46 showed no inhibitory effect on $\mathrm{LTD}_{4}$-induced bronchoconstriction with indomethacin treatment, and elicited significant inhibition on contractile responses induced by $L_{T D}$ in lung parenchymal but not tracheal strips. Furthermore, evidences to indicate peptide LTs can release $\mathrm{TXA}_{2}$ from guinea pig lung parenchymal strips (14) and perfused lung (23) have been documented. Therefore, it is conceivable that the inhibitory effect of OKY046 on LTs-induced bronchoconstriction is attributable to inhibition of $\mathrm{TXA}_{2}$ generation in peripheral airways. An attenuation of the initial phase of bronchoconstriction by indomethacin (similar to OKY-046) is probably due to suppression of $\mathrm{TXA}_{2}$ production in peripheral airways.

PAF is released from perfused guinea pig lungs in response to antigen (24). Furthermore. Lagente et al. (25) demonstrated that Ro 19-3704, a PAF antagonist, inhibits anaphvlactic bronchoconstriction. These evidences suggest the possible involvement of PAF in antigen-induced bronchoconstriction. We confirmed the potent spasmogenic activity of PAF (Fig. 5). Although PAF-induced bronchoconstriction was inhibited by OKY046 and indomethacin. it seems unlikely that the inhibitory effects of these two compounds were attributed to direct antagonisms against PAF since the hypotensive responses induced by i.v. administration of PAF were not affected by these two compounds. PAF induces platelet-dependent bronchoconstriction (26) and stimulates the release of $\mathrm{TXA}_{2}$ from guinea pig lung tissue (27). Furthermore, PAF causes platelet aggregation, platelet and neutrophil diapedesis immediately after its systemic administration in guinea pigs (25, 28). Therefore, it is possible that the inhibitory effects of OKY-046 and indomethacin against PAF-induced bronchoconstrictions are attributable to the inhibition of PAF-induced $\mathrm{TXA}_{2}$ generation through platelet aggregation.

OKY-046 attenuated the pressor response induced by peptide LTs, PAF and antigen in accordance with the inhibitory activity on the airway response. In addition, Katsura et al. (29) reported that $\mathrm{STA}_{2}$ caused both bronchoconstriction and the pressor response. Therefore, TXA 2 is most likely to be involved in peptide LTs-, PAF - and antigen-induced responses if assessed by responses of the blood pressure. 
Histamine is considered as a potent mediator in bronchoconstriction following antigen challenges in guinea pigs $(30,31)$. OKY046 had no inhibitory effects against the contractile responses induced by exogenous histamine. Accordingly, it is unlikely that the antiasthmatic effect of OKY-O46 is due to antagonism on the contractile action of histamine.

Indomethacin did not elicit any effect on antigen-induced bronchoconstriction except 1 min after antigen challenge (Fig. 1). Krell et al. (32) and Hitchcock (33) reported that indomethacin potentiates the contractile responses to peptide LTs and antigen in isolated guinea pig tracheae. There are several explanations for the failure of indomethacin to inhibit antigen-induced bronchoconstriction. First, indomethacin potentiates histamine release from basophils and airway tissues ( 34 . 35). Secondly, indomethacin suppresses the synthesis of bronchodilating PGs, such as $\mathrm{PGI}_{2}$ (9), and/or causes the shunt of arachidonic acid to the 5-lipoxygenase pathway (36).

In conclusion, we demonstrated that $O K Y$ 046 inhibited antigen-induced anaphylactic bronchoconstrictions in sensitized guinea pigs in vivo. The inhibitory effect of OKY -046 is probably due to the inhibition of $\mathrm{TXA}_{2}$ production directly from an antigen-antibody reaction and/or indirectly via peptide LTs or PAF in the peripheral airways.

Acknowledgment: The authors are grateful to Dr. F.W. Foong for his constructive comments during the preparation of this manuscript.

\section{References}

1 Dahlen, S.E., Hansson, G., Hedquist, P., Bjorck, I., Granstrom, E. and Dahlen, B.: Allergen challenge of lung tissue from asthmatics elicits bronchial contraction that correlates with the release of leukotriene $\mathrm{C}_{4}, \mathrm{D}_{4}$ and $\mathrm{E}_{4}$. Proc. Natl. Acad. Sci. U.S.A. 80, 1712-1716 (1983)

2 Schu!man, E.S., Adkinson, N.F., Jr. and Newball, H.H.: Cyclooxygenase metabolites in human lung anaphylaxis: airway vs. parenchyma. J. Appl. Physiol. 53, 589-595 (1982)

3 Lands, W.E.M.: The biosynthesis and metabolism of prostaglandins. Annu. Rev. Physiol. 41, 633652 (1979)

4 Samuelsson, B., Goldyne, M., Granstrom, E, Hamberg, M., Hammarstrom, S. and Malmsten,
C.: Prostaglandins and thromboxanes. Annu. Rev. Biochem. 47, 997-1029 (1978)

5 Schleimer, R.P., Schulman, E.S., MacGlashan, D.W., Jr., Peters, S.P., Hayes, E.C., Adams, G.K., III, Lichtenstein, L.M. and Adkinson, N.F., Jr.: Effect of dexamethason on mediator release from human lung fragments and purified human lung mast cells. J. Clin. Invest. 71, 1830-1835 (1983)

6 Schleimer, R.P., MacGlashan, D.W., Jr., Peters, S.P., Pinckard, R.N., Adkinson, N.F., Jr. and Lichtenstein, L.M.: Characterization of inflammatory mediator release from purified human lung mast cells. Am. Rev. Respir. Dis. 133, 614617 (1986)

7 Schulman, E.S., Newball, H.H., Demers, L.M., Fitzpatrick, F.A. and Adkinson. N.F., Jr.: Anaphylactic release of thromboxane $A_{2}$, prostaglandin $\mathrm{D}_{2}$ and prostacyclin from human lung parenchyma. Am. Rev. Respir. Dis. 124, 402406 (1981)

8 Whittle, B.J.R. and Moncada, S.: Pharmacological interactions between prostacyclin and thromboxanes. Br. Med. Bull. 39, 232-238 (1983)

9 Moncada, S. and Vane, J.R.: Pharmacology and endogenous role of prostaglandin endoperoxides. thromboxane $A_{2}$ and prostacyclin. Pharmacol. Rev. 30, 293-331 (1978)

10 Hiraku, S., Taniguchi, K., Wakitani, K., Omawari, N., Kira, H., Miyamoto, T., Okegawa, T., Kawasaki, A. and Ujiie, A.: Pharmacological studies on the TXA $\mathrm{A}_{2}$ synthetase inhibitor; (E)-3-[p-(1Himidazol-1-ylmethyl\}phenyl]-2-propenoic acid (OKY-046). Japan. J. Pharmacol. 41, 393-401 (1986)

11 Levine, B.B., Chang, H., Jr. and Vaz, N.M.: Production of hapten-specific reaginic antibodies in the guinea pig. J. Immunol. 106, 2933 (1971)

12 Findlay, S.R., Lichtenstein, L.M., Hanahan, D.J. and Pinckard, R.N.: Contraction of guinea pig ileal smooth muscle by acetyl glyceryl ether phosphorylcholine. Am. J. Physiol. 241, C130C133 (1981)

13 Weichman, B.M., Muccitelli, R.M., Osborn, R.R., Holden, D.A., Gleason, J.G. and Wasserman, M.A.: In vitro and in vivo mechanisms of leukotriene-mediated bronchoconstriction in the guinea pigs. J. Pharmacol. Exp. Ther. 222, 202208 (1982)

14 Creese, B.R., Bach, M.K., Fitzpatrick, F.A. and Bothwell, W.M.: Leukotriene-induced contraction and thromboxane production in guineapig lung parenchymal strips. Eur. J. Pharmacol. 
$102,197-204(1984)$

15 Burka, J.F., Ali, M., McDonald, J.W.D and Paterson, N.A.M.: Imınunological and nonimmunologica! synthesis and release of prostaglandins and thromboxanes from isolated guinea pig trachea. Prostaglandins 22, 683-691 (1981)

16 Ally, A.i., Boucher, R., Knowles, M.R. and Eling, T.E.: Metabolism of prostaglandin endoperoxide by microsomes from human lung parenchyma and comparison with metabolites produced by pig, bovine, rat, mouse and guinea-pig. Prostaglandins 24, 575-584 (1982)

17 Turner, N.C. and Dollery, C.T.: Release of arachidonic acid metabolites and histamine from guinea-pig lung following antigen challenge. Br. J. Pharmacol. 93, 751-758 (1988)

18 Drazen, J.M., Austen, K.F., Lewis, R.A., Clark, D.A., Goto, G., Marfat, A. and Corey, E.J.: Comparative airway and vescular activities of leukotriene $C-1$ and $D$ in vivo and in vitro. Proc. Natl. Acad. Sci. U.S.A. 77, 4354-4358 (1980)

19 Drazen, J.M., Venugopalan, C.S., Austen, K.F., Brion, F. and Corey, E.J.: Effect of leukotriene $E$ on pulmonary mechanics in the guiriea pig. Am. Rev. Respir. Dis. 125, 290-294 (1982)

20 Hedquist, P., Dahlen, S.E., Gustafsson, L., Hammarstrom, $S$ and Samuelsson, B.: Biologica! profile of leukotriene $\mathrm{C}_{4}$ and $\mathrm{D}_{4}$. Acta Physiol. Scand. 1 10, 331-333 (1980)

21 Sirois, P., Roy, S., Tetrault, J.P., Borgeat, P., Picard, S. and Corey, E.J.: Pharmacological activity of leukotriene $A_{4}, B_{4}, C_{4}$ and $D_{4}$ on selected guinea pig, rat, rabbit and human smooth muscles. Prostaglandins Med. 7, 327340 (1981)

22 Andersson, P.: Effects of inhibitors of anaphylactic mediators in two models of bronchial anaphylaxis in anesthetized guinea-pigs. Br. J. Pharmacol. 77, 301-307 (1982)

23 Nagai, H., Yakuo, M., Togawa, M., Arimura, A., Matsuura, N., Koda, A., Hamano, S., Ujiie, A. and Nakazawa, M.: Effect of OKY-046, a new thrornboxane $\mathrm{A}_{2}$ synthetase inhibitor, on experimental asthma in guinea pigs. Prostaglandins Leukotrienes. Med. 30,111-121 (1987)

24 Fitzgerald, M.F., Moncada, S. and Parente, L.: The anaphylactic release of platelet activating factor from perfused guinea-pig lungs. Br. J. Pharmacol. 88, 149-153(1986)

25 Lagente, V., Desquand, S., Hadvary, P., Cirino, M., Lellouch-Tubiana, A., Lefort, J. and Vargaftig, B.B.: Interference of the Paf antagonist Ro 19-3704 with Paf and antigen-induced broinchoconstriction in the guinea-pig. Br. J.
Pharmacol. 94, 27-36 (1988)

26 Vargaftig, B.B., Lefort, J., Chignard, M. and Benveniste, $J .:$ Platelet-activating factor induces a platelet-dependent bronchoconstriction unrelated to the formation of prostaglandin derivatives. Eur. J. Pharmacol. 65, 185-192 (1980)

27 Lefort, J., Rotilio, D. and Vargaftig, B.B.: The platelet-independent release of thromboxane $A_{2}$ by Paf-acether from guinea-pig lungs involves mechanisms distinct from those for leukotriene. Br. J. Pharmacol. 82, 565-575 (1984)

28 Lellouch-Tubiana, A., Lefort, J., Pirotzky, E., Vargaftig, B.B. and Pfister, A.: Ultrastructural evidences for extravascular platelet recruitment in the lung upon intravenous injection of platelet-activating factor (PAF-acether) to guinea-pigs. Br. J. Exp. Pathol. 66, 345-355 (1985)

29 Katsura, M., Miyamoto, T., Hamanaka, N., Terada, T., Ohgaki, Y., Kawasaki, A. and Tsuboshima, M.: In vitro and in vivo effects of new powerful thromboxane antagonists (3-alkylamino pinane derivatives). Adv. Prostaglandin Thromboxane Leukotriene Res. 11, 351-357 (1983)

30 Bartosch, R., Feldberg, W. and Nagel, E.: Weitere Versuche über das Freiwerden eines histaminahnlichen Stoffes aus der durchstromten Lunge sensibilisieter meerschweinchen beim auslosen einer anaphylaktischen Lungenstarre. Pflugers Arch. 231, 616-629 (1932)

31 Payne, A.N. and de Nucci, G.: Anaphylaxis in guinea pigs induced by ovalbumin aerosol: In vivo and in vitro methods. J. Pharmacol. Methods 17. 83-90 (1987)

32 Krell, R.D., Osborn, R., Vickery, L., Falcone, K., O'Donnell, M., Gleason, J.r Kinzig, $C$, and Bryan, D.: Contraction of isolated airway smooth muscle by synthetic leukotriene $C_{4}$ and $D_{4}$. Prostaglandins 22, 387-409 (1981)

33 Hitchcock, M.: Stimulation of the antigeninduced contraction of guinea-pig trachea and immunological release of histamine and SRS-A from sensitized guinea-pig lung by (2-isopropyl-3-indoyl) -3 pyridyl ketone ( $L$ 8027) and indomethacin. Br. I. Pharmacol. 71, 65-73 (1980)

34 Undem, B.J., Pickett, W.C., Lichtenstein, L.M. and Adams, G.K., Ill.: The effect of indomethacin on immunologic release of histamine and sulfidopeptide leukotrienes from human bronchus and lung parenchyma. Am. Rev. Respir. Dis. 136. 1183-1187 (1987)

35 von der Helm, D., Ring, J. and Dorsch, W.: Comparison of histamine release and prosta. 
glandin $E_{2}$ production of human basophils in atopic and normal individuals. Arch. Dermatol. Res. 279, 536-542 (1987)

36 Obata, T., Katsube, N., Miyamoto, T., Toda, M., Okegawa, T., Nakai, H., Kosuge, S., Konno, M.,
Arai, Y. and Kawasaki, A.: New antagonists of leukotrienes: ONO-RS-411 and ONO-RS-347. Adv. Prostaglandin Thromboxane Leukotriene Res. 15, 229-231 (1985) 